\title{
Harassment Matters: Perception of Students on Hazardity of Political, Religious, Economic, Sexual and Social Harassment in the Academia
}

\section{Bala Ibrahim Sambo ${ }^{1}$}

\author{
${ }^{1}$ Department of Education. School of Continuing Education. Bayero University. Kano, \\ Nigeria.
}

\section{Article History}

Received:

27.09.2020

Revised:

25.11.2020

Accepted:

02.12 .2020

*Corresponding Author:

Bala Ibrahim Sambo.

Email:

bisambo.sce@buk.edu.ng

This is an open access article, licensed under: $\mathrm{CC}-\mathrm{BY}-\mathrm{SA}$

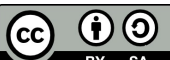

Abstract: This study investigated the perception students have on the relative hazardity of political, religious, economic, sexual and social harassment on students. Four hundred students were drawn as research respondents through convenience and stratified sampling techniques. Using Likert type scale, respondents were requested to indicate the level of hazard of each political, religious, economic, sexual and social harassment (PRESS) factor using $5=$ very hazardous; $4=$ hazardous; $3=$ neutral; 2 = not hazardous; $1=$ less hazardous. Digital interview was used to obtain data from the respondents. Frequency counts, percentage, relative importance index and chi square were used to analyse the data. Results indicated that the PRESS factors were perceived as hazardous by students; however, contrary to popular belief that sexual harassment was most hazardous, the results indicated that religious harassment was the most hazardous; sexual harassment was second; economic harassment was third; political harassment was fourth; and social harassment was fifth. Based on the findings, it was recommended that harassment factors should be addressed according to their magnitude; and that addressing harassment behaviour should be holistic and comprehensive. Furthermore, education of stakeholders should take the issue of harassment serious by being proactive.

Keywords: Economic Harassment, Political Harassment, Religious Harassment, Sexual Harassment, Social Harassment. 


\section{Introduction}

The School of Continuing Education (SCE), with its management headed by a dean, who is supported by a Deputy Dean, Sub-Deans Academic and Facilities, four Heads of Departments and the Administrative Secretary as well as an Accountant [1].

There are four departments ie. Arts and Humanities, Education, Sciences and Social Sciences. The Arts and Humanities Department runs courses tagged as B. A. (Arabic), B. A. (English), B. A. (Hausa), and B. A. (Islamic Studies). The Education Department runs courses tagged as B. A. (Ed) Arabic; B. A. (Ed) English; B. A. (Ed) Hausa; and B. A. (Ed) Islamic Studies. In addition, the Department of Education runs courses such as B. Sc. Library Science; B. A. (Ed) Adult Education; and B.Sc. (Ed) Mathematics. The Department of Sciences runs courses such as B.Sc. Geography; B.Sc. (Nursing); and B.Sc. Mathematics. The Department of Social Sciences runs courses such as B.Sc. (Accounting), B.Sc. (Economics), and B.Sc. (Criminology).

The part-time programme was run from Friday $-1400 \mathrm{hrs}$ to Saturday $-1800 \mathrm{hrs}$ weekly. The duration of the programme was $150 \%$ of regular undergraduate courses as stipulated by the by government [2]. The mode of instruction was face-to-face. Put into compendious perspective, the students register for all the courses regular undergraduates register. The only difference between the two programmes is in the duration (4years for regular undergraduates and $5 \frac{1}{2}$ years for part-time undergraduates). Students are admitted with minimum of Advanced Certificate, National Certificate of Education level with considerable years of working experience; and that they must have been 25 years of age. Students start from Level II; and go through to Levels III, IV, V and VI to complete degree programmes offered in SCE.

\section{Literature Review}

Harassment is a social relationship phenomenon that occurs in universities the worldwide. It is defined as any intended and repetitive communication, verbal or non-verbal, between the powerful and the powerless, which is not based on common concept [3]. Harassment can also be viewed as any behaviour that appears to be disturbing, upsetting or threatening; and that it has an effect of nullifying or impairing a person from benefiting his/her rights and privileges [4]. Harassment, under the laws of the United States, is defined as any repeated or continuing uninvited contact that serves no useful purpose beyond creating alarm, annoyance, or emotional distress. Harassment usually takes the quid pro quo and hostile work environment. In most cases, harassment inflicts harm or distress on the victims [5].

Some studies have found that harassment behaviour could be expressed either directly or indirectly [6]. Direct harassment includes bold request and any communication that is unequivocally connoting unacceptable request. Indirect harassment includes any communication which points to unacceptable request but can be denied such as indecent dressing, playing with body parts and so on [6].

In order to review the concept of harassment, the author intends to do so using a harassment postulation acronym PRESS, which represents political, religious, economic, sexual and social harassment as follows:

\subsection{Political Harassment}

In academia, political harassment is said to have taken place when the lecturer (the powerful) makes the student (the powerless) follows, serves or campaigns for the lecture's political preference without the consent of the student [7]. An example is a situation where a lecturer attaches some importance, usually awarding marks in Continuous Assessment or the Semester Examination, to students who campaign for and/or attend a rally of the lecturer's political activities or his political associates.

In the academia political harassment could extend to students' activities such as election of the Students' Union Government. Some lecturers go as far as making it compulsory for students to elect representatives of the lecturers' choice. It is no more a secret that public politics has infiltrated into universities [7]. Some politicians identify their supporters with colour, dress or appearance and students are made to identify with colour, dress or appearance their lecturers belong to; it could a cap, bids or party tee-shirts [7].

\section{Religious Harassment}

Although very little attention has been given to religious harassment, it is one of the fastest growing harassment phenomena in the academia [8]. By way of definition, religious harassment is said to 
occur when the lecturer (the powerful) treats or segregates students (the powerless) based on their religious beliefs. It is also postulated that requiring students to abandon or change their religious beliefs as a condition of passing a lecture's course, and unwelcome and pervasive comments or behaviours regarding their religions that create a hostile or abusive feeling results in low self-efficacy [3]. For example, a lecturer may attach some importance, usually awarding marks in Continuous Assessment or the Semester Examination, to students who belong to his religion. In academia, according to [9] the most pronounced religious harassment occurs between people of the same religion but different denominations; such as Orthodox and Protestant in Christianity; Dariqah and Izalah in Islam. This is called, Intra-Religious Harassment [9].

Some lecturers demand from students to attend a monthly religious meeting of the lecturers' religions or denominations if the students wish to either pass or get a good grade [10]. A lecturer may change the time or date of his lectures on days or times that are normally religious and emphasise the importance of attendance on that very day or time. Similarly, a lecturer may decree that students must attend his/her religious propagation meetings. When a student declines, the consequence is undesirable [11].

\subsection{Economic Harassment}

Economic harassment, as social science concept, refers to engaging in activities which force students to make financial contributions to the course or activity of a lecturer [12]. Such activities include sell of handouts, books, magazines, or any material used in the teaching/learning process. Studies pointed out that economic harassment is much pronounced in the postgraduate programmes, especially professional programmes, where the 'big and rich students' undergo studies.

The new and sudden influx of women into the labour market brought about two simultaneous, but seemingly opposite reactions to women at work [13]. Some men resented female employees and perceived them as a threat in traditionally male dominated work environments [14]. Hence, women were subjected to overt discrimination, that is, they received lesser-valued job assignments, lack of promotions, lower pay, and economic harassment to cause embarrassment and humiliation. It is insinuated that if sex discrimination forces women into lower-paying jobs, economic harassment helps keep them there and the situation is the same in the academia [14].

\subsection{Sexual Harassment}

The most controversial harassment topology is sexual harassment. The concept of sexual harassment can be viewed simply as any sexual communication in nature, which generally includes unwanted sexual advances, conduct or behaviour. It could also be viewed as an unwelcome sexual advance, requests for sexual favours, and other verbal or physical conduct of a sexual nature [14]. In the academia, it takes the form of quid pro quo - sex for marks. Sexual harassment includes but not restricted to sharing sexual photos (pornography), posting sexual posters, inappropriate sexual touching, inappropriate sexual gestures, invading personal space in a sexual way, as well as sexual comments, jokes, questions and other forms of communication that are sexual in connotation [15].

At this juncture, it should be pointed out that there are times when the scenario in sexual harassment takes the unusual dimension - students harassing the lecturers. Students blackmail lecturers to sleep with them; they entice lecturers in various ways. For instance, positive studentlecturer relationships have been found to ameliorate the negative effect of harassment on boys' academic achievement [16] and served as a protective factor for victimization from kindergarten to first grade [17] [18].

\subsection{Social Harassment}

Social harassment can be defined as any unwelcome communication, usually unwelcome remarks or expensive jokes based on victim's sex, tribe, religious orientation, disability, gender identity or gender expression by the victimiser [19]. For example, making mockery of one's hijab, physical appearance, threat to safety and so on. Such harassment is made either explicitly or implicitly. Social harassment may inflict harm or distress on the victim including physical, psychological, or educational harm. The issue of social harassment is so important that [19] stated becoming is the deeply personal reckoning of a woman of soul and substance who has steadily defied expectations--and whose story inspires us to do the same. 


\subsection{Statement of Problem}

Recently the nation has been engulfed on the issue of sexual harassment in tertiary institutions. Focussing on sexual harassment is miniature in scope. Hence, this study looked at the problem of harassment covering political, religious, economic, sexual and social harassment.

Purpose of the Study

The purpose of the study was to investigate whether the components of PRESS are equally hazardous to students with a view to proposing the attention each factor deserved based on its ranking.

Based on the purpose of the study, the research question was postulated:

- Do students perceive the hazardous nature of PRESS factors equally?

The research hypothesis emanating from the research question was as follows:

- Ho: PRESS factors were perceived as equally hazardous.

\subsection{Conceptual Framework}

Currently the issue of harassment, particularly sexual harassment has been the focus of the bureaucrats, technocrats, academics as well as the public. Considerable attention is paid to sexual harassment against students in tertiary institutions. Series of postulations have been propounded by scholars and other stakeholders [14] [21].

The issues about harassment could be examined by answering the questions:

- What types of harassment students experience in school?

- How hazardous are the harassment experienced in school is?

The first question answered by proposing PRESS as the types of harassment experienced by students in school.

This study would attempt to answer the second question.

In terms of theories about harassment of students in school, the study postulated a theoretical framework as contained in Figure 1.

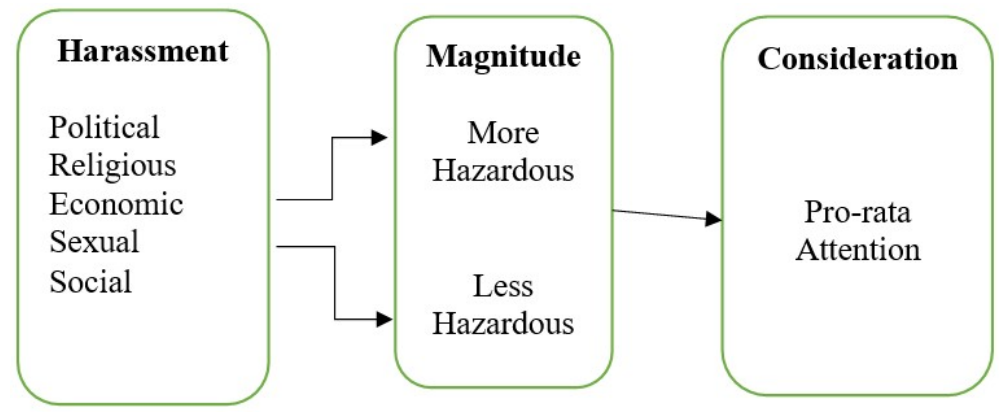

Figure 1. Theoretical Framework

Harassment of students is as old as the formal education [4, 14]. Hitherto attention had been more on sexual harassment in tertiary education or place of work Gazmararian and Julie [14] stated that sexual harassment is not a new phenomenon in tertiary institutions which according to him has been receiving considerable attention in research and the media of which public awareness for it has increased significantly and dramatically. Sexual harassment in tertiary institutions and workplaces had been given a lot of attention so much so that the U.S. Equal Employment Opportunity Commission (1999) enacted a policy on sexual harassment. In other words, efforts on addressing harassment is heavily biased in favour of sexual harassment; thereby ignoring other important harassment dimensions in tertiary institutions and workplace. Conceptual framework of this study postulates that efforts on handling harassment should be comprehensive, wholistic and all encompassing. And to address the issue of harassment in a comprehensive manner, the study postulated a PRESS harassment behaviour framework. 


\section{Methodology}

Data were collected from 400 student-respondents in the School of Continuing Education, Bayero University, Kano. Students were contacted through their mobile phone numbers to inquire if they would volunteer to partake in the research. The respondents were students who volunteered to partake in the research. The respondents were selected through stratified sampling; the strata being students in SCE as well as students in Levels III, IV, V, and VI. In addition, convenience sampling; a sampling technique where a group of respondents are drawn from that part of the population (SCE) was used [22].

The research instrument used in conducting the survey contained five dimensions of harassment comprising

1. Political

2. Religious

3. Economical

4. Sexual

5. Social.

Likert Type items presented as PRESS formed the content of the instrument. The research hypothesis is, the five factors of harassment are equally hazardous. For the research hypothesis, respondents were instructed to rate the PRESS harassment factors on a 5-point Likert-type scale ranging:

$$
\begin{aligned}
& 5=\text { Very Hazardous } \\
& 4=\text { Hazardous } \\
& 3=\text { Neutral } \\
& 2=\text { Not Hazardous } \\
& 1=\text { Less Hazardous. }
\end{aligned}
$$

The research instrument was administered through interview method by research assistants. There was no missing response; hence there was a hundred percent instrument return rate. In order to test the hypothesis, the Relative Importance Index (RII) was used. The choice of RII was informed by the fact that even though some tests could be used to analyse the data, RII was most appropriate because it allows for the identification of the important indicators or items drawn from respondents' responses as well as prioritise the factors [22]. The chi square (X2) test statistics was used to find out if the finding was statistically significant.

The procedure used to analyse the obtained data was divided into three stages:

1. Calculating frequency distribution of participants' responses

2. Ranking of each factor as perceived by the respondents by calculating the relative importance index

3. Calculating the degree of difference between the press factors.

It should be noted that the term 'importance' is used to connote hazard. Hence, the more important a factor is, the more hazardous it is; and the less important a factor is, the less hazardous it is.

\section{Finding and Discussion}

Result for the Frequency Distribution of PRESS Response can be seen in Table 1.

\subsection{Political Harassment}

The results in Table 1 were condensed and modified to ensure succinctness. In this vein, the terms "very hazardous" and "hazardous" were merged and represented by the term "hazardous"; and the terms, "not hazardous" and "less hazardous" represented by "not hazardous".

The results revealed that forty-nine (49) respondents representing a little over sixty-eight percent $(68.1 \%)$ stated that political harassment was hazardous $(n=72)$; and twenty-one $(21)$ respondents representing a little over twenty-nine percent (29.2\%) stated that political harassment is not hazardous $(\mathrm{n}=72)$. Only two $(2)$ respondents representing nearly three percent $(2.8 \%)$ were neutral $(n=72)$. Summarily, sixty-eight percent $(68 \%)$ of respondents opined that political harassment was hazardous to students $(\mathrm{n}=72)$. 
Table 1. Frequency Distribution of PRESS Response

\begin{tabular}{|c|c|c|c|c|c|c|c|c|}
\hline & & & $\begin{array}{c}\text { Very } \\
\text { Hazardou } \\
\text { s }\end{array}$ & $\begin{array}{c}\text { Hazardou } \\
\text { s }\end{array}$ & Neutral & $\begin{array}{c}\text { Not } \\
\text { Hazardous }\end{array}$ & $\begin{array}{c}\text { Less } \\
\text { Hazardou } \\
\text { s }\end{array}$ & Total \\
\hline \multirow{15}{*}{ Press } & \multirow{3}{*}{ Political } & Count & 19 & 30 & 2 & 11 & 10 & 72 \\
\hline & & Expected & 22.0 & 32.8 & 2.9 & 7.7 & 6.7 & 72.0 \\
\hline & & $\%$ within & $15.6 \%$ & $16.5 \%$ & $12.5 \%$ & $25.6 \%$ & $27.0 \%$ & $18.0 \%$ \\
\hline & \multirow{3}{*}{ Religious } & Count & 39 & 51 & 3 & 4 & 4 & 101 \\
\hline & & Expected & 30.8 & 46.0 & 4.0 & 10.9 & 9.3 & 101.0 \\
\hline & & $\%$ within & $32.0 \%$ & $28.0 \%$ & $18.8 \%$ & $9.3 \%$ & $10.8 \%$ & $25.3 \%$ \\
\hline & \multirow{3}{*}{ Economical } & Count & 20 & 35 & 3 & 11 & 9 & 78 \\
\hline & & Expected & 23.8 & 35.5 & 3.1 & 8.4 & 7.2 & 78.0 \\
\hline & & $\%$ within & $16.4 \%$ & $19.2 \%$ & $18.8 \%$ & $25.6 \%$ & $24.3 \%$ & $19.5 \%$ \\
\hline & \multirow{3}{*}{ Sexual } & Count & 30 & 40 & 3 & 11 & 10 & 94 \\
\hline & & Expected & 28.7 & 42.8 & 3.8 & 10.1 & 8.7 & 94.0 \\
\hline & & $\%$ within & $24.6 \%$ & $22.0 \%$ & $18.8 \%$ & $25.6 \%$ & $27.0 \%$ & $23.5 \%$ \\
\hline & \multirow{3}{*}{ Social } & Count & 14 & 26 & 5 & 6 & 4 & 55 \\
\hline & & Expected & 16.8 & 25.0 & 2.2 & 5.9 & 5.1 & 55.0 \\
\hline & & $\%$ within & $11.5 \%$ & $14.3 \%$ & $31.3 \%$ & $14.0 \%$ & $10.8 \%$ & $13.8 \%$ \\
\hline \multirow{3}{*}{ Total } & & Count & 122 & 182 & 16 & 43 & 37 & 400 \\
\hline & & Expected & 122.0 & 182.0 & 16.0 & 43.0 & 37.0 & 400.0 \\
\hline & & $\%$ within & $100.0 \%$ & $100.0 \%$ & $100.0 \%$ & $100.0 \%$ & $100.0 \%$ & $100.0 \%$ \\
\hline
\end{tabular}

\subsection{Religious Harassment}

The results in Table 1 also revealed that ninety (90) respondents representing a little over eighty-nine percent $(89.1 \%)$ stated that political harassment was hazardous $(\mathrm{n}=101)$; and eight $(8)$ respondents representing nearly early eight percent $(7.9 \%)$ stated that political harassment is not hazardous $(\mathrm{n}=$ 101). Only three (3) respondents representing nearly three percent $(2.9 \%)$ were neutral $(\mathrm{n}=101)$. Summarily, eighty-nine percent $(89 \%)$ of the respondents opined religious harassment was hazardous to students $(\mathrm{n}=101)$.

\subsection{Economic Harassment}

The results in Table 1 also revealed that fifty-five (55) respondents representing nearly seventy-one $(70.5 \%)$ stated that economic harassment was hazardous $(\mathrm{n}=94)$; and twenty-one $(21)$ respondents representing a little over twenty-two percent $(22.3 \%)$ stated that political harassment is not hazardous $(\mathrm{n}=94)$. Only three $(3)$ respondents representing nearly ten percent $(9.6 \%)$ were neutral $(\mathrm{n}=94)$. Summarily, summarily, seventy-one percent $(71 \%)$ of the respondents opined that economic harassment was hazardous to students $(\mathrm{n}=94)$.

\section{a. Sexual Harassment}

Results in Table 1 also revealed that seventy (70) respondents representing nearly seventy-five percent $(74.5 \%)$ stated that sexual harassment was hazardous $(\mathrm{n}=94)$; and twenty-one $(21)$ respondents representing nearly early twenty-two percent $(22.3 \%)$ stated that sexual harassment is not hazardous $(\mathrm{n}=94)$. Only three $(3)$ respondents representing a little over three percent $(3.2 \%)$ were neutral $(\mathrm{n}=94)$. Summarily, seventy-five percent $(75 \%)$ of the respondents opined that sexual harassment was hazardous to students $(\mathrm{n}=94)$. 


\section{b. Social Harassment}

The results in Table 1 also revealed that forty (40) respondents representing a little over seventy-three percent $(72.8 \%)$ stated that political harassment was hazardous $(n=55)$; and ten $(10)$ respondents representing a little over eighteen percent $(18.2 \%)$ stated that social harassment is not hazardous $(\mathrm{n}=$ $55)$. Only five (5) respondents representing a little over nine percent $(9.1 \%)$ were neutral $(\mathrm{n}=55)$. Summarily, seventy-three percent $(73 \%)$ of the respondents opined that political harassment was hazardous to students $(\mathrm{n}=55)$.

Table 2. Relative Importance Index Analysis

\begin{tabular}{l|c|c|c|c|c|c|c|r|r|r|} 
& $\begin{array}{c}\text { Very } \\
\text { Hazardous } \\
\mathbf{5}\end{array}$ & $\begin{array}{c}\text { Hazardous } \\
\mathbf{4}\end{array}$ & $\begin{array}{c}\text { Neutral } \\
\mathbf{3}\end{array}$ & $\begin{array}{c}\text { Not } \\
\text { Hazardous } \\
\mathbf{2}\end{array}$ & $\begin{array}{c}\text { Less } \\
\text { Hazardous } \\
\mathbf{1}\end{array}$ & Total & $\begin{array}{c}\text { Total } \\
\text { Number } \\
(\mathbf{N})\end{array}$ & $\mathbf{N}^{*} \mathbf{A}$ & RII & Importance \\
\hline Political & 95 & 120 & 15 & 22 & 10 & 253 & 400 & 2000 & $\begin{array}{r}0.12 \\
65\end{array}$ & $4^{\text {th }}$ \\
\hline Religious & 180 & 192 & 9 & 8 & 4 & 393 & 400 & 2000 & $\begin{array}{r}0.19 \\
65\end{array}$ & $1^{\text {st }}$ \\
\hline Economic & 115 & 140 & 9 & 22 & 9 & 280 & 400 & 2000 & $\begin{array}{r}0.14 \\
00\end{array}$ & $3^{\text {rd }}$ \\
\hline Sexual & 150 & 160 & 9 & 22 & 10 & 351 & 400 & 2000 & $\begin{array}{r}0.17 \\
55\end{array}$ & $2^{\text {nd }}$ \\
\hline Social & 70 & 104 & 15 & 12 & 4 & 205 & 400 & 2000 & $\begin{array}{r}0.10 \\
25\end{array}$ & $5^{\text {th }}$ \\
\hline
\end{tabular}

The contributions of each PRESS factor were examined through ranking of its hazard as perceived, which was carried out by using Relative Importance Index (RII). The RII was calculated by using the following the Eq. 1:

$$
\mathrm{RII}=\sum \frac{W}{A N N}=\sum \frac{5 n_{5}+4 n_{4}+3 n_{3}+2 n_{2}+1 n_{1}}{A^{4} N}
$$

Where,

$\mathrm{W}=$ Weight respondents give to each of the PRESS factors

A $=$ Highest weight (in this case 5)

$\mathrm{N}=$ Total number of respondents

The RII in Table 2 revealed that students perceived PRESS factors as hazardous. However, the main issue of contention is how much each factor is hazardous. The view that PRESS factors were all viewed as hazardous emanated from the factor no factor was left unanswered. Each factor received responses based on the perception of the students on how important that factor is. At this juncture, it must be added that the value of RII should a fraction of 1 such as .1; 01 and so on.

Table 2 revealed the relative importance of each PRESS factor. The RII of political harassment is $0.1265(13 \%)$ bagging 4th position; religious harassment is $0.1965(20 \%)$ bagging 1st position; economic harassment is 0.1400 (14\%) bagging 3rd position; sexual harassment is $0.1756(18 \%)$ bagging 2nd position; and social harassment is 0.1025 bagging 5 th position.

Table 3. Ranking of the PRESS Factors

\begin{tabular}{lrc}
\hline \multicolumn{1}{c}{ Factor } & RII & Importance \\
\hline Religious Harassment & 0.9650 & $1^{\text {st }}$ \\
\hline Sexual Harassment & 0.7560 & $2^{\text {nd }}$ \\
\hline Economic Harassment & 0.1400 & $3^{\text {rd }}$ \\
\hline Political Harassment & 0.1265 & $4^{\text {th }}$ \\
\hline Social Harassment & 0.1025 & $5^{\text {th }}$ \\
\hline
\end{tabular}


The factors ranking them accordingly shown in Table 3. Table 3 revealed the relative importance of each of the PRESS factors. According to the result religious is ranked as first; and sexual ranked as second; economical harassment ranked as third; political harassment political harassment ranked as fourth; and social harassment and fifth. However, attention must be focussed on the magnitude of a factor. Religious harassment is not only the first, but also its magnitude is very far away from the other factors: Religious vs Sexual $=20 \%$; Religious vs Econ $86 \%$; Religious vs Pol $=84 \%$; and Religious vs Social $=86 \%$.

Table 4. Test Statistics

\begin{tabular}{|cccc|}
\hline Null Hypothesis & Test & Sig. & Decision \\
\hline $1 \begin{array}{l}\text { The categories of Press occur with } \\
\text { equal probabilities. }\end{array}$ & $\begin{array}{l}\text { Onample } \\
\text { Chi-Square } \\
\text { Test }\end{array}$ & .002 & $\begin{array}{l}\text { Reject the } \\
\text { null } \\
\text { hypothesis. }\end{array}$ \\
\hline
\end{tabular}

Asymptotic significances are displayed. The signific ance level is 05 .

Now that we have established the relative importance of each PRESS factor, we have to determine the statistical significance of the ranking. In order to do this, we use chi square test (X2) statistics. The research hypothesis, PRESS factors are equally hazardous, which the SPSS presented as the categories of PRESS occur with equal probabilities in table 4 was analysed using SPSS. The test statistics reveals that even though the significance level was .05 for an accurate and correct decision, the significance level revealed in the study was .002 , which was far less than the benchmark significance. The test statistics depicted that the null hypothesis be rejected $(\mathrm{X} 2=16.65 ; \mathrm{Df}=4 ; \mathrm{CV}$ $=18.46 ; \mathrm{P}<.002)$. This implies that PRESS factors were not viewed as equally hazardous - some are more hazardous than the others.

\section{Conclusion}

The main goal of this study was to find out whether sexual harassment was the only harassment factor that was affecting students in Nigeria's tertiary institutions. This concern emanate from the attention sexual harassment has been accorded by government, institutions, and the general public. The research postulated five harassment factors PRESS and investigated whether the five factors were equally hazardous.

First, the study found out that all the five harassment factors were considered hazardous at one point or the other. This was in conformity with the findings of [15] that stressed the hazardousness of harassment to academic performance. Hence, the need to address harassment holistically. It should be borne in mind that government and other stakeholders in education do not usually take proactive approach in handling problems. It is when a problem arises that they start to pay attention to it. By the time a solution is arrived at, the issue would have been over taken by other events [15].

Second, the five harassment factors differed in magnitude or frequency. The most hazardous harassment as revealed by the research was religious. Religious harassment $=0.9650$; sexual harassment $=0.7560$; Economic harassment $=0.1400$; Political harassment $=0.1265$; and Social harassment $=0.1025$. The difference was so large that there was $21 \%$ range between religious harassment and the next most hazardous harassment, sexual harassment (religious 0.9650; sexual $0.7560=0.21 * 100$ ). Similarly, the difference between religious harassment and the other three PRESS factors was more $80 \%$ compared with factor.

Third, religious harassment was considered as the most hazardous. Contrary to the popular sentiment that sexual harassment was the most hazardous harassment in the nation, the results depicted that sexual harassment, even though hazardous, was $20 \%$ lower in hazardity than religious harassment. Hence, giving sexual harassment the most importance in terms of hazardity is misplacement of priority. This is not saying that sexual harassment should not receive attention.

Fourth, sexual harassment, even considered as very hazardous, it was second to religious harassment in hazardity. This implies that it is not the most hazardous harassment factor. However, it must be borne in mind that despite the fact that sexual harassment is not the most hazardous 
harassment factor; it is still a very hazardous factor. It falls within the 3rd Quartile in terms of ranking; the same with the religious harassment. The hazardity of sexual harassment is shared by many scholars [8] [14] [15] [16] [17] [21].

Based on the findings of the study, the researcher strongly recommends attention be given to all the PRESS factors. However, the attention accorded to each PRESS factor should be prioritised on basis of its relative hazard - pro rata basis. There is also the need for tertiary institutions to come up with comprehensive policy documents addressing the PRESS factors as guides against harassment of students. Furthermore, an elaborate stakeholders' harassment education programmes should be organised and conducted. Tertiary institutions should earmark a day for assessing the managing of harassments, which may be tagged, "Harassment Free Day".

\section{References}

[1] Bayero University, BUK-Annual Report. Kano, 2018.

[2] Federal Republic of Nigeria, National Universities Commission [NUC], 2019.

[3] H. G. Muhammad, "The Essence and Purpose of Adult Education and Community Development (Ed)," Department of Adult Education, Bayero University, Kano, 2019.

[4] A. R. Baugher, Gazmararian, A. Julie, "Masculine gender role stress and violence: A literature review and future directions," Aggression and Violent Behaviour, vol. 24, pp. 107-112, 2015. doi:10.1016/j.avb.2015.04.002.

[5] T. E. Waadorp, E. T. Pas, L. M. O'Brennan, and C. P. Bradshaw, "A multilevel perspective on the climate of harassment: Discrepancies among students, school staff, and parents," Journal of School Violence, vol. 10, pp. 115-132, 2011. doi: 10.1080/15388220.2010.539164

[6] J. Joseph, "Sexual Harassment in Tertiary Institutions: A Comparative Perspective," Temida 2015, vol 18, no. 2, pp. 125-144, 2015. [Online]. Available: https://doi.org/10.2298/ TEM1502125H. [Accessed: January 2020].

[7] Daniele, Gianmarco, "Strike One to Educate One Hundred: Organized Crime, Political Selection, and Politicians' Ability." Journal of Economic Behavior \& Organization, vol. 159, pp. 650-662, 2019. [Online]. Available: 10.1016/j.jebo.2017.07.021. [Accessed: January 2020].

[8] D. O. Omonijo, O. C. O. Uche, K. L. Nwadiafor, O. A. Rotimi, "A Study of Sexual Harassment in Three Selected Private Faith Based Universities, Ogun State, South-west Nigeria," Open Journal of Social Science Research, vol. 9, pp. 250-263, 2013.

[9] A. K. Aliyu, B. Modu, and C. W. Tan, "A review of renewable energy development in Africa: A focus in South Africa, Egypt and Nigeria," Renewable and Sustainable Energy Reviews, vol. 81, pp. 2502-2518, 2015.

[10] J. Schipper, Religion, Race, and the Wife of Ham. The University of Chicago Press, 2020.

[11] B. McGinnin, Reminder: Religious Discrimination and Harassment is Still a Serious Issue, 2018.

[12] I. Muhwezi, and G. Otim, "An assessment of the factors causing delay on building construction project in Uganda," International Journal of Construction Engineering and Management, vol. 3, no. 1, pp. 13-23, 2014.

[13] U.S. Equal Employment Opportunity Commission, Sexual harassment, 1999. [Online]. Available: http://www.eeoc.gov/laws/types/sexual_harassment.cfm. [Accessed: January. 23, 2020].

[14] A. Mamaru, K. Getachew, Y. Mohammed, "Prevalence of Physical, Verbal and Nonverbal Sexual Harassments and Their Association with Psychological Distress among Jimma University Female Students: A Cross-sectional Study," Ethiopian Journal of Health Sciences, vol. 1, pp. 29-38, 2015.

[15] K. Jodi and T. Megan, SHE SAID: Breaking the Sexual Harassment Story that Helped Ignite a Movement. Penguin Press, 2019.

[16] T. Stephens and J. Hallas, Bullying and Sexual Harassment: A Practical Handbook. Publisher: Random House Large Print Publishing, 2017.

[17] Cobb, Ellen Pinkos, Sexual Harassment Law Evolving Globally, 2014. [Online]. Available: http://www.shrm.org/hrdisciplines/global/articles/pages/sexual-harassment-lawglobal.aspx.

[Accessed: June. 24, 2020]. 
[18] M. K. Holt, K. Raczynski, K. S. Frey, S. Hymel, and S. P. Limber, "School and communitybased approaches for preventing harassment," Journal of School Violence, vol. 12, pp. 238252, 2013. doi: 10.1080/15388220.2013.792271. [Accessed: January 2020].

[19] M. Obama, Becoming. Crown Publishing Group (NY), 2017.

[20] R. Murray-Harvey and P. T. Slee, "School and home relationships and their impact on school harassment," School Psychology International, vol. 31, pp. 271-295, 2010. doi: 10.1177/014303431 0366206.

[21] M. O. Taiwo, O. C. Omole, and O. E. Omole, "Sexual Harassment and Psychological Consequence Among Students in Higher Education Institution in Osun State, Nigeria," International Journal of Applied Psychology, vol. 1, pp. 13-18, 2014.

[22] J. W. Creswell and J. D. Creswell, Research Design: Qualitative, Quantitative, and Mixed Methods Approaches. 5th ed. SAGE Publishing, 2020. 